\title{
IMPLEMENTING SMART CITY STRATEGIES AS AN INNOVATIVE PRACTICE FOR COVID -19 PANDEMIC IN EGYPTIAN CONTEXT
}

\author{
${ }^{1}$ Salma Magdy Mohamed, ${ }^{1}$ Dalia Moati, ${ }^{1}$ Marwa Adel Elsayed \\ ${ }^{1}$ The British University in Egypt (BUE), Faculty of Engineering, Architectural Engineering Department, El Sherouk City, Egypt \\ (salma160398@bue.edu.eg, dalia.moati@bue.edu.eg, marwa.adel@bue.edu.eg)
}

KEY WORDS: Smart cities - Implementing Smart Strategies - COVID-19 Pandemic - Egypt - Integrating Technology-GIS

\begin{abstract}
:
Pandemics have always shaped cities throughout history, and numerous health challenges have been reflected in architecture and urban design. Today, the globe is dealing with a COVID-19 pandemic, which is maybe the worst in history. Coronavirus (COVID19) sparks a critical debate about how to use smart technology's concepts and insights to urban planning and architecture. As a result of the recent pandemic, this commentary sheds light on considerations and challenges in the area of knowledge in these fields. As a result, it is now more vital than ever for policymakers at the local, regional, and national levels to begin developing smart city and Internet of Things plans. The Smart Cities Mission is a government-led project to promote economic growth and development across four strategic planning pillars: city improvement, city rehabilitation, city extension (Greenfield development), and pan-city development. This study discusses numerous obstacles and constraints in three categories: technical, socioeconomic, and environmental. This paper intends to investigate the feasibility of applying technology in an existing city and transforming it into a smart city using the most advanced technologies, as well as smart strategies and automated judgments; the research uses the 10th of Ramadan city as a case study. In addition, the predicted outcome of this article is the implementation of smart city policies as a best practise for the COVID-19 pandemic in Egypt. Finally, it is predicted that more cities would use technology into their strategy in the future.
\end{abstract}

\section{INTRODUCTION}

In late 2019 and early 2020, a few cases of unexplained condition showed up in Wuhan, China. The disease was determined to be caused by a new coronavirus, and the ailment was given the name 2019 coronavirus infection (COVID-19). Coronavirus has a huge negative impact on city growth, according to recent polls. Many cities weren't able to face the pandemic in its early ages which led to total lockdown affecting the economy of cities (Allam and Dhunny, 2019).

Furthermore, the global fight against COVID-19 is centred on smart measures. Smart technology can help kick start and sharpen economic recovery by not just eradicating and confining the virus, but also by investing in smart strategies and supporting digital infrastructure. So, moving towards implementing smart cities strategies is considered a must for now and for the future (Samsonov, 2018).

Developing different smart GIS scenarios for current Egyptian cities may assist planner in facing covid-19 pandemic through implementing different smart strategies. As current Egyptian cities do not have smart strategies in place, and their future plans do not appear to incorporate smart technologies into their architecture. As a result, smart technology must be incorporated by city planners when developing cities(Bowman et al., 2015) (Elsayed and Ismaeel, 2019). The paper aims to implement scenarios of different smart strategies to formalize a GIS pilot model for In the current Egyptian setting of the COVID-19 epidemic, planners propose implementing smart city methods in the process of tracking and confronting the pandemic in a current Egyptian context transferring it to smart city by planners during COVID-19 pandemic

\subsection{Site Description}

The selected case study for implementing smart city strategies is 10th of Ramadan as it is considered one of the most developed cities over the past 30 years as the largest industrial city in Egypt. The city is considered an industrial city and at the same times a Residential city which give the change to examine different perspectives. Also, one of the reasons of selection is the availability data of GIS database.

The 10th of Ramadan was established in 1977 as associate integrated town with access to Cairo, Port Said, Ismailia and Suez shown in fig.1. The population of 10th of Ramadan city is calculated to be 511987. Originally the city aimed toward housing all sections of the society, however it's instead developed as associate industrial town over time and also the housing focused on the low cost phase. Tenth of Ramadan is considered a hot and arid climate. The city cordon is coming up with Ministry of Housing, Utilities and concrete Development with area 9534.88Fadden, encompassing a town border with a region 18118.144 Fadden(GOPP, 2021). A small percentage of green belt had been cultivated and still most of the areas allocated to green belt square are still vacant lands that encourage the indiscriminate extensions. The subsequent figure shows this land use of 10th of Ramadan, it contains 11 hospitals and healthcare, 35 colleges and academic institutes, 1400 factories, 34 business centres, 2 telephone centres, 27 social centres, 2 hotels , and 15 bank (GOPP, 2021).

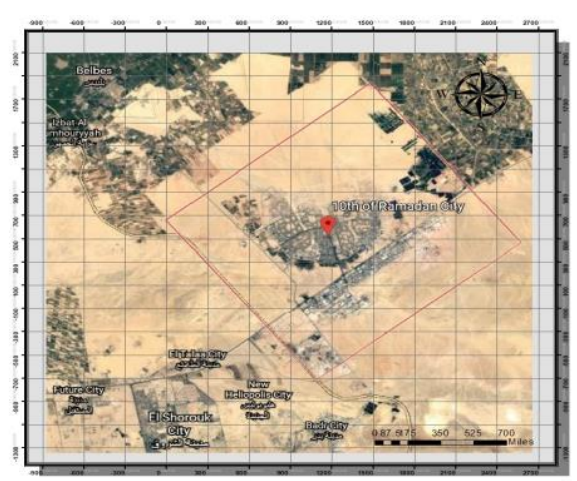

Figure 1. Location for the area of interest 


\subsection{Covid-19 And City Development}

COVID-19, according to recent studies, might be a huge burden for both rich and poor communities. Because of their economic structure, their preparedness for such a crisis, particularly the state of their public health and repair delivery systems, and the extent to which their population's health and livelihoods are vulnerable, the measures taken to manage the spread of the virus are having massive implications on cities (Lorente, Arrabal and Pulido-Montes, 2020)The COVID-19 pandemic shook the world when it first broke out, with new cases and deaths increasing by more than $20 \%$ each day in the main hotspots, as shown In below fig.2. With such a high incidence, the disease was predicted to spread across the community in just six months if no measures were taken, and to reach a peak after three months, when 30 percent of the population would be infected.(Lorente, Arrabal and Pulido-Montes, 2020)

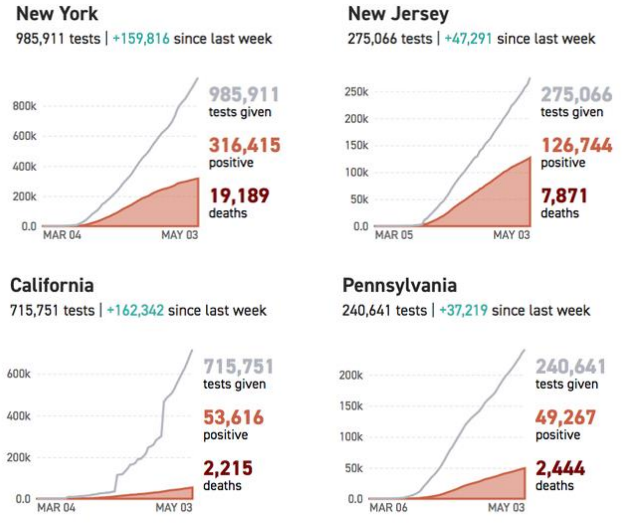

Figure 2. Corona cases graphs (Beatrice Jin .2021)

The COVID-19 pandemic has so far been marked by a quick increase in new cases, followed by a peak and more unpredictable behaviour that differs by region.(Lorente, Arrabal and Pulido-Montes, 2020) The virus wasn't able to be traced in the cities, emphasising on the lack of technologies focusing on the importance of smart cities. smart cities means combining both the information and communication technology (ICT) with the IOT network for improving the efficiency of city processes and facilities connected with citizens.(Bowman et al., 2015)It is critical to evaluate the obstacles and limitations of growth, performance, and inhabitants' lives in order to improve quality of life. As a result, new measures to improve city performance and sustainability must be devised. (Ben Letaifa, 2015). Strategies that are based on technology and the ability to manage data information.6 main domains:

1. Living and health,

2. Government and economy

3. Education

4. Mobility system

5. Safety and protection

6. energy

The foremost technologies are technologies that combine clever methods to create a smart high-tech metropolis Information and communication technology (ICT) offers the necessary infrastructure for connecting entities in a smart city, including network technologies, authentication, and access, as well as security mechanisms. (Bifulco, Tregua, Amitrano, 2016).Other Technology aids in the development of a successful smart city. Predictive and preventive judgments are formed, deduced and understood, and then decisions are made to make residents' lives easier, using machine learning and deep learning technology.
(Batty, 2018; Allam and Dhunny, 2019). And Using artificial intelligent technologies.

GIS stands for geographic information system, which is a conceived framework for capturing and analysing geographical and geographic data. GIS apps are computer-based tools that allow users to create interactive queries, save and change geographical and non-spatial data, and visually convey the results of such processes by displaying them as maps (Clarke, 1986).Engineering, planning, management, transportation, telecommunications, and business are just a few of the processes and applications that use geographic information systems.(Maliene et al., 2011) presented in fig.27 and fig.28. Through the use of Locations and Extents that are discovered inside the Earth's space-time and recorded using $\mathrm{x}, \mathrm{y}$, and $\mathrm{z}$ coordinates, GIS enables the ability to connect previously unrelated information. (Samsonov, 2018)

\subsection{Studies And Scenarios Of Implementation}

More studies ,Research (Abou and Seoud, 2014) attempts to define which smartness initiatives make the Egyptian cities 'Smart City' by conducted face to face interview with 40 architecture and urban planner experts. The average score given by the 40 experts for the importance of each of the twenty two given smart system components within the Egyptian smart cities.(Wu et al., 2016) The interview listed twenty two major smart system components of smart cities recorded in all smart cities literature. The twenty two given smart component systems were classified according to the main smart initiatives of smart cities and the average scoring of each smart initiative were determined to identify the main characteristics of the Egyptian smart cities. The results show that the smart mobility, infrastructure and smart governance are the main initiatives of the Egyptian smart cities.(Abou and Seoud, 2014)

In India Allahabad city was proposed an integration of strategies for elaborating the city to become smart $n$ 2017.Allahabad Smart City Projects would be completed over a period of 5 Years after successful selection. According to (Govt. of India, 2017) there are different worldwide scenarios for each criteria in every strategy in order to document the state of the city to implement the right smart strategies. Each criteria consists of four scenarios as follows starting with Smart Infrastructure Strategy:

Enable Information and Communication Technology (ICT) Services Strategy:

1st Scenario: No linkage between platforms and government 2nd Scenario: Some services are online

3rd Scenario: Most services are online and offline

4th Scenario: all services are offline and online platforms

\section{Water supply and Management Strategy:}

1st Scenario: Poor water system with not enough water treatment and waste water isn't recycled

2nd Scenario: Medium water system, some rainwater harvesting 3rd Scenario: All Waste water treated, some recycled meeting high standards. Rainwater harvesting

4th Scenario: Zero water waste, as all water is collected and recycled for a secondary use; as rain water harvesting

\section{Energy Source Strategy:}

1st Scenario: consume energy without generating any source of energy with no renewable energy

2nd Scenario: Future Plans for obtaining renewable sources 3rd Scenario: Some renewable energy resources

4th Scenario: Energy used > 10\% from renewable resources 
Sanitation Strategy:

1st Scenario: limited areas have access to sanitation facilities and infra-structure

2nd Scenario: Access for $70 \%$ of population in city 3rd Scenario: Access for $90 \%$ of population in city 4th Scenario: Access for $100 \%$ of population in city

Moreover, continuing to (Govt. of India, 2017) . Each criteria of

Smart Mobility Strategy consists of four scenarios as follows that are also worldwide scenarios:

Public / private Transportation condition Strategy:

1st Scenario: limited public transportation, so more vehicles causing Air and noise pollution

2nd Scenario: More roads for less congestion (some public transportation) but expensive for poor people

3rd Scenario: Network streets, paths in most areas, safe crossing and security (public transportation covering most of the area) 4th Scenario: Safe and secure crossing, walkability and cycling (Clear Network streets, many transportation covering all cities)

Mobility around the city other than transportation (Walkability) Strategy:

1st Scenario: few pavement lacking trees, not safe walking and no road crossing signs

2nd Scenario: containing few good quality pavements with trees 3rd Scenario: Good cycling lanes and pavements in network with trees, easily access to building from pavements

4th Scenario: (Cycling lanes and Sidewalks with High quality Pavements in all streets, having Trees), Building are accessible from sidewalks, Traffic Signs control

\section{Parking Strategy:}

1st Scenario: Cars park parallel to pavements (no parking areas) 2nd Scenario: (parking lots are separated) from the road 3rd Scenario: Large driveways and (parking)

4th Scenario: (High technology parking monitoring)

\section{Traffic Strategy:}

1st Scenario: No Traffic Control system

2nd Scenario: Traffic Control systems are disobeyed

3rd Scenario: Traffic control is sometimes disobeyed and difficult to cross the street

4th Scenario: High technological Traffic system control that are enforced for high safety of auto-mobility

In addition, each criteria of Smart Government Strategy consists of worldwide scenarios as follows ,and this strategy contains only two criteria's:

\section{Citizen participation Strategy:}

1st Scenario: City starts to understand the priorities and projects to pursue without citizens consultation

2nd Scenario: Citizen selects stakeholders and share with only few major decisions

3rd Scenario: citizen full participation at local city level 4th Scenario: Citizen full engagement to combine all views in order to shape the priorities and development of project

\section{Economy and Employment Strategy:}

1st Scenario: informal sector jobs without enough facilities 2nd Scenario: Range of jobs that reach many sections of city, informal economic activities integrate with formal 3rd Scenario: Many jobs for all sections, challenge skill level 4th Scenario: Many jobs for all skill levels and all sections of society (skill trainings provided and supported by city)
This demonstrates that the ability to choose solutions that can be implemented in a present Egyptian city is a result of the literature review. According to the case studies a comparison was made to identify the criteria used in each strategy and it was resulted that smart infrastructure, smart mobility and smart government were a priority in both cases and were assured by (Abou \& Seoud, 2014) that any city in Egypt can become smart by changing these three strategies to smart. Then (Govt. of India, 2017) has mentioned that in order to change a current city that already exists into a smart city, it is essential to document the state of the city; to identify the suitable implementation needed for each strategy. Thus, this documentation is done through worldwide scenarios for every city depending on its situation and conditions (Govt. of India, 2017).which is going to assist in implementing these strategies while enabling technologies and smart applications.

\section{RESEARCH METHOD}

This paper adopts a Technological Mixed Methodology primarily, accommodating both qualitative and quantitative set of data through 3 phases. Phase 1: Collection of data - Phase 2: data reduction phase - Phase 3: data integration.

Phase (1) is carried through the following step:

Step1: Data gathering stage: Archival / Documents for worldwide scenarios of the strategies where a set of qualitative and quantitative data gathered from different sources (maps, statistics, charts, reports ... etc.)On the three strategies (smart government, smart mobility and smart infrastructure)

Phase (2) Data Reduction and display is carried through the following steps:

Step2: a survey questionnaire is used for users and experts in order to fill the table of implementation, describing the current state of the city and aim state in order to fill the table of implementation. Shown in table 1

\begin{tabular}{|c|c|c|c|}
\hline Criteria & Questions & Current & Aim \\
\hline \multirow{5}{*}{$\begin{array}{l}\text { Enable } \\
\text { (ICT) } \\
\text { Services }\end{array}$} & \multicolumn{3}{|c|}{ What is the Services condition in the city? } \\
\hline & \multicolumn{3}{|l|}{$\begin{array}{l}\text { 1.No linkage between } \\
\text { platforms and government } \\
\text { services }\end{array}$} \\
\hline & \multicolumn{3}{|l|}{ Some services are online } \\
\hline & \multicolumn{3}{|l|}{$\begin{array}{l}\text { Most services are online } \\
\text { and offline }\end{array}$} \\
\hline & \multicolumn{3}{|l|}{$\begin{array}{l}\text { all services are through } \\
\text { offline and online platforms }\end{array}$} \\
\hline \multirow{5}{*}{$\begin{array}{l}\text { Water } \\
\text { supply and } \\
\text { Managem } \\
\text { ent }\end{array}$} & \multicolumn{3}{|c|}{ What is the water condition in the city? } \\
\hline & \multicolumn{3}{|l|}{$\begin{array}{l}\text { Poor water system with not } \\
\text { enough water treatment. } \\
\text { Also, waste water isn't } \\
\text { recycled }\end{array}$} \\
\hline & \multicolumn{3}{|l|}{$\begin{array}{l}\text { Treated Medium water } \\
\text { system, Some rain water } \\
\text { Harvesting.) }\end{array}$} \\
\hline & \multicolumn{3}{|l|}{$\begin{array}{l}\text { All Waste water treated, } \\
\text { some recycled ,Rainwater } \\
\text { harvesting and system does } \\
\text { not meet standards }\end{array}$} \\
\hline & \multicolumn{3}{|l|}{$\begin{array}{l}\text { Zero water waste, recycled } \\
\text { for a secondary use } \\
\text { as rain water harvesting }\end{array}$} \\
\hline \multirow{4}{*}{$\begin{array}{l}\text { Energy } \\
\text { Source }\end{array}$} & \multicolumn{3}{|c|}{ What is the energy source condition in the city? } \\
\hline & \multicolumn{3}{|l|}{ no renewable energy } \\
\hline & \multicolumn{3}{|l|}{$\begin{array}{l}\text { Has Future Plans } \\
\text { renewable sources }\end{array}$} \\
\hline & Some renewable energy & & \\
\hline
\end{tabular}




\begin{tabular}{|c|c|c|}
\hline \multirow{7}{*}{\begin{tabular}{|l|} 
Sanitation \\
\end{tabular}} & resources & \\
\hline & $\begin{array}{l}\text { Energy used at least } 10 \% \\
\text { from renewable resources }\end{array}$ & \\
\hline & \multicolumn{2}{|c|}{ What is the sanitation condition in the city? } \\
\hline & $\begin{array}{l}\text { Not all areas have access to } \\
\text { sanitation facilities and } \\
\text { infrastructure }\end{array}$ & \\
\hline & $\begin{array}{l}70 \% \text { of population in city } \\
\text { have access to Sanitation } \\
\text { facilities }\end{array}$ & \\
\hline & $\begin{array}{l}90 \% \text { of population in city } \\
\text { have access to Sanitation } \\
\text { facilities }\end{array}$ & \\
\hline & $\begin{array}{l}100 \% \text { of population in city } \\
\text { have access to Sanitation } \\
\text { facilities }\end{array}$ & \\
\hline \multirow{5}{*}{$\begin{array}{l}\text { Mobility } \\
\text { around the } \\
\text { city other } \\
\text { than } \\
\text { transportat } \\
\text { ion(walka } \\
\text { bility) }\end{array}$} & \multicolumn{2}{|c|}{ What is the mobility condition in the city? } \\
\hline & $\begin{array}{l}\text { few pavement lacking trees, } \\
\text { not safe walking and no } \\
\text { road crossing signs }\end{array}$ & \\
\hline & $\begin{array}{l}\text { containing few good quality } \\
\text { pavements with trees }\end{array}$ & \\
\hline & $\begin{array}{l}\text { Good cycling lanes and } \\
\text { pavements in network with } \\
\text { trees }\end{array}$ & \\
\hline & $\begin{array}{l}\text { Cycling lanes } \text { and } \\
\text { Sidewalks with High } \\
\text { quality Pavements in all } \\
\text { streets, having Trees }\end{array}$ & \\
\hline \multirow[t]{5}{*}{$\begin{array}{l}\text { Transporta } \\
\text { tion }\end{array}$} & \multicolumn{2}{|c|}{$\begin{array}{l}\text { What is the condition of transportation in the } \\
\text { city? }\end{array}$} \\
\hline & $\begin{array}{l}\text { 1. Limited } \\
\text { transportation, so molic } \\
\text { vehicles }\end{array}$ & \\
\hline & $\begin{array}{l}\text { 2.restrictive } \\
\text { transportation }\end{array}$ & \\
\hline & $\begin{array}{l}\text { 3.Public transportation } \\
\text { covering most of the area }\end{array}$ & \\
\hline & $\begin{array}{l}\text { 4.Clear Network streets and } \\
\text { many transportation options } \\
\text { that covers all city }\end{array}$ & \\
\hline \multirow[t]{5}{*}{ Parking } & \multicolumn{2}{|c|}{ What is the condition of Parking in the city? } \\
\hline & no parking areas & \\
\hline & $\begin{array}{l}\text { parking lots are sometimes } \\
\text { separated from roads }\end{array}$ & \\
\hline & $\begin{array}{l}\text { parking lots are en-closed } \\
\text { by gates }\end{array}$ & \\
\hline & $\begin{array}{l}\text { High technology parking } \\
\text { monitoring }\end{array}$ & \\
\hline \multirow[t]{5}{*}{$\begin{array}{l}\text { Traffic } \\
\text { control }\end{array}$} & \multicolumn{2}{|c|}{$\begin{array}{l}\text { What is the condition of Traffic control in the } \\
\text { city? }\end{array}$} \\
\hline & No Traffic Control systems & \\
\hline & $\begin{array}{l}\text { Traffic Control systems are } \\
\text { often Disobeyed }\end{array}$ & \\
\hline & $\begin{array}{l}\text { Traffic control are } \\
\text { sometimes disobeyed and } \\
\text { difficult to cross the street }\end{array}$ & \\
\hline & $\begin{array}{l}\text { High technological Traffic } \\
\text { system control }\end{array}$ & \\
\hline \multirow{4}{*}{$\begin{array}{l}\text { Citizen } \\
\text { participati } \\
\text { on }\end{array}$} & \multicolumn{2}{|c|}{$\begin{array}{l}\text { What is the Citizen participation condition in } \\
\text { the city? }\end{array}$} \\
\hline & not sharing with citizens & \\
\hline & $\begin{array}{l}\text { share with only few major } \\
\text { decisions }\end{array}$ & \\
\hline & citizen full participation at & \\
\hline
\end{tabular}

\begin{tabular}{|c|c|c|}
\hline & local level and city level & \\
\hline & $\begin{array}{l}\text { citizen full participation at } \\
\text { each ward level }\end{array}$ & \\
\hline \multirow{5}{*}{$\begin{array}{l}\text { Economy } \\
\text { and } \\
\text { Employme } \\
\text { nt }\end{array}$} & \multicolumn{2}{|c|}{$\begin{array}{l}\text { What is the Economy and Employment } \\
\text { condition in the city? }\end{array}$} \\
\hline & $\begin{array}{l}\text { many informal sector jobs } \\
\text { without enough facilities }\end{array}$ & \\
\hline & $\begin{array}{l}\text { informal economic } \\
\text { activities integrate with } \\
\text { formal parts of city }\end{array}$ & \\
\hline & skill level is a challenge & \\
\hline & $\begin{array}{l}\text { skill trainings provided and } \\
\text { supported by city }\end{array}$ & \\
\hline
\end{tabular}

Table 1. Survey Questionnaire

Conclusion of the survey questionnaire, the Current state and aim state of 10th of Ramadan city showing the scenarios that have the highest percentage approval in each criteria of every strategy. This conclusion is presented in the form of individual responses.

Step3: the implementation stage applied using 3 steps- 1 . Observations, analysis and the impact on covid-19 pandemic2.application of enabled technologies-3.GIS pilot model and map. For each strategy

The observations will describe the situation of the city concluded from the survey and analyzing it showing how will it affect covid-19

\section{Smart infrastructure strategy observations and impact on covid-19:}

Information and Communication Technology (ICT) had a huge role in facing covid-19 by maintain the physical distance between people; therefore lowering the rate of infection. One the other hand, maintaining the social connection while providing services needed for virtual education and business meeting.

Rain water is not used and left in streets without a system to getting rid of the excessive water. Leading to road blockage and street damaging .also, increasing the speed of viruses and deceasing spreading through the untreated bad water condition. Affect covid-19 by preventing environmental pollution that cause the rabid increase of diseases and rate of infection.

Energy sources are limited. In addition, citizens consume energy without generating any source of renewable energy in their daily life making nearly impossible to obtain certain high technological feature that need a large amount of energy in order to work.

Clean source of energy to be used in hospitals as a backup energy source in case of emergencies .Also, analysis for more than one factor to recognize all symptoms of covid-19 need a huge amount of energy in many devices that will make this analysis.

Technological advanced techniques of treatment prevent environmental pollution in many sectors of the city which allows more control on the spread of the virus. Sanitation station in the 10th of Ramadan city. Not all areas have access to sanitation facilities and infra-structure

\section{Smart Mobility strategy observations and the impact on} covid-19:

Smart transportation allows QR code for suspicion of covid-19 giving data on any infected person paths and the safe space distance with auto-paying technology. In the city, Bus doesn't meet the right social distance sufficient to avoid spreading of the virus Greater chance of becoming affected by any virus Reducing congestions and change behaviour of pedestrians to improve their health and ability to overcome the virus. Which 
increase the rate of facing covid-19. Sidewalks have no any precaution for facing a pandemic. Not safe walking and no road crossing signs. Walking in city may be difficult as the pavements in need of repair. There is no sidewalk furniture for pedestrians to rest.

Reducing parking search through high technological systems. Better quality of air; as vehicle emissions are also reduced and so less diseases. Ability to reach to hospitals fast in case of emergencies. Unorganized parking may lead to timeconsuming. In addition to decreasing the quality of air with the $\mathrm{Co} 2$ emissions and if emergencies happened the ambulance will not be able to reach its destination.

Traffic control technology systems deduct the real-time conditions; enabling flow of traffic data to be sent to vehicles and road crossing for increasing the safety. Impact on covid-19: Decrease the direct communication between pedestrians; as instead of traffic man managing the traffic, readjusting his job by using smart traffic control systems.

\section{Smart Government strategy observations and the impact on covid-19:}

Citizens in smart cities shapes city with their views and opinions for achieving better city benefits and strategies. Impact on covid-19: Support people's need in case of any pandemic including their health

A smart city has resilient economic base that

increases employmentopportunities for the majority of its citize ns. Impact on covid-19: Affording the technologies and medical systems needed to face any pandemic in its early stages. In order to decreasing lockdown.

The implementation and the application of enabled technologies, showing target scenarios and the state of the city will be shown as follows for the three smart strategies: smart infrastructure, smart mobility and smart Government:

\section{A. Smart Infrastructure Strategy:}

This strategy contains four criteria , each criteria showing target scenarios and the state of the city followed by implementation.

\section{Enable Information and Communication Technology (ICT)}

The city current state is the 2 nd scenario aiming to target the 4 th scenario and it will be implemented by integrate all government services and unified billing under one umbrella for easy control and monitoring. This would also make the system more transparent and the concerned departments accountable for the services offered to citizen. Android Apps need to be created for to increase transparency and accountability

\section{Water supply and Management}

The city current state is the 1st Scenario aiming to target the 4th scenario and it will be implemented by 1 . Using rain water harvesting systems. Smart technological shading devices that include the system of water collection. 2. Automated water treatment systems; using data collecting with sensor systems and Data cloud. Then linked to the city with ICT

\section{Energy Source}

The city current state is the 1 st Scenario aiming to target the 4 th scenario and it will be implemented by 1 . Using multiple sources of energy. Obtaining energy from footpath by converting the kinetic energy of people walking into electric energy that is later used for city needs 2 . Using solar panels on both parking shades and home roofs for obtaining the energy needed for homes and becoming zero energy consumption.

\section{Sanitation}

The city current state the 1 st Scenario and aimed to target the 4 th scenario and it will be implemented by 1 . Self-cleaning and sanitizing. 2. making random virus test on pedestrians to assure the health condition of each district on the city to track and trace the virus.

\section{B. Smart Mobility Strategy:}

This strategy contains also four criteria , each criteria showing target scenarios and the state of the city followed by implementation.

\section{Public / private Transportation condition}

The city current state the 1 stscenario and aimed to target the 4th scenario and it will be implemented by 1 . A) Bus shelter equipped with ultraviolet light air sterilizers for preventing transmission of airborne viruses. The air sterilizer breaks up 96 to $99 \%$ of virus particles, according to Song Jun-myoung, a chief of policy managing division at the office who managed the project. B)An intelligent camera shows when buses are approaching to the station through a digital screen installed inside. C) Automatic screen door blocks people with a high fever from entering the booth after checking their body temperature with a thermal imaging camera. 2. Buses are paid and reserved through a QR code; to avoid personal interaction. Social distance and automatic sterilizing techniques. Coronavirus-fighting smart bus.

\section{Mobility around the city other than transportation(walkability)}

The city current state the 1 stscenario and aimed to target the 4th scenario and it will be implemented by 1 . Sidewalk has Camera scanners that scan the health of any person walked by in seconds to compare the symptoms and detect if that person have possibility of Covid-19 or not. Notify and warn all people surrounding and identify any person was in contact with infected person 2. Sidewalks have sensors in the floor close when crossing the road to alarm any coming vehicle. Vehicle alert of a person is about to walk and the traffic lights automatically turned red. A pedestrian is safely crossing the road.

\section{Parking}

The city current state the 1stscenario and aimed to target the 4 th scenario and it will be implemented by 1 . Smart parking development implies an IOT-based system that sends data about free and occupied parking places via web/mobile application. The IOT-device, including sensors and microcontrollers, is located in every parking space 2 . vertical parking, also called "industrial parking" helps in increasing the area of parking while maintaining the land of city with other usage like greenery for better quality of life.

\section{Traffic control}

The city current state the 1 stscenario and aimed to target the 4th scenario and it will be implemented by 1 . The smart automated road divider system .This system is activated in rush hour when it is the most traffic. The lane moved in 30 seconds from 1 lane to another to allow an extra lane for the traffic road in a 2 way roads. 2. The smart traffic system is based on multiple sources/ data collected from deducting movements of cars and speeds and predicting their path, then light signals are activated in order to fasten the movements of cars ,and decreasing co 2 emissions. (all traffic lights are connected and linked ) 


\section{A. Smart Infrastructure Strategy:}

This strategy contains only two criteria, each criteria showing target scenarios and the state of the city followed by implementation.

\section{Citizen participation}

The city current state the 1stscenario and aimed to target the 4th scenario and it will be implemented by 1 improve delivery of services to citizens, businesses and employees and engage citizens in the process of governance through interaction. These centres provide ease of access towards utility payments, grievance redressed with increased transparency of the system 2.Applications on the mobile phones for participation in polls 3 . Developing GIS based map including the digitization of land records, and monitoring system connected with Command Control Centre will increase the efficiency in functioning of governing system resulting in betterment of citizen services.

\section{Government and Economy}

The city current state the 1stscenario and aimed to target the 4 th scenario and it will be implemented by 1 . Automation of administrative process: allowing the immediate data identification and transformation when inserting personal ID. Retrieving the application of the government services to be used to minimize time and documents regarding budgeting, accounting and data flow. Using big data block chain and security protocols. 2. smart card: ID involves multiple data regarding all governmental documents such as: personal information, driving license, credit card, hand print and home documents ;having a secure key .used for payment ,medical insurance and history, and penalties.

Services Strategy: Phase (3) data integration and applying of GIS

Step 4: Data modelling design by making a pilot GIS of scenarios, through the use of Buffer analysis, Overlay all relevant environment datasets, Convert the vector layer to raster, Reclassify the raster layers and Apply raster tools. In order to; monitoring map to follow up implantation and sketching out scenarios.

Smart infrastructure strategy GIS pilot model and map: These models and maps will be presented in Fig.3,4,5 and 6 bellow for each criteria.
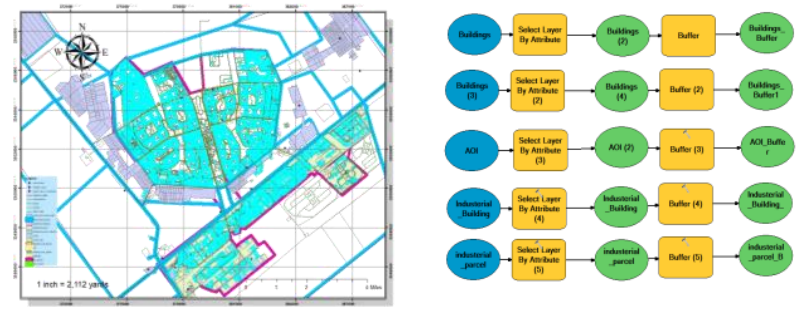

Figure 3. Information and Communication Technology (ICT)
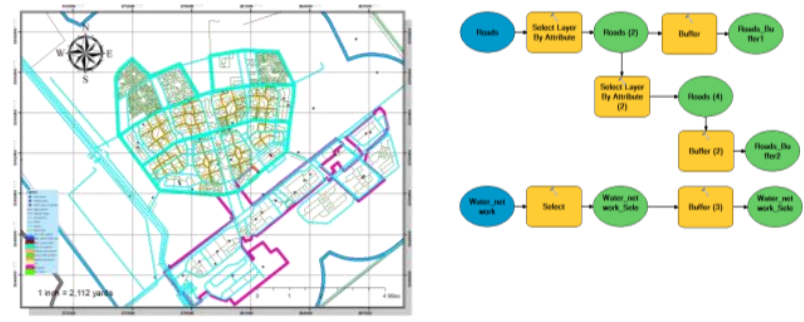

Figure 4. Water supply and Management
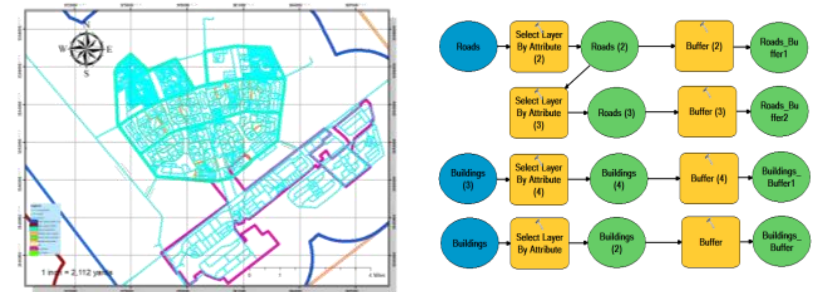

Figure 5. Energy Source
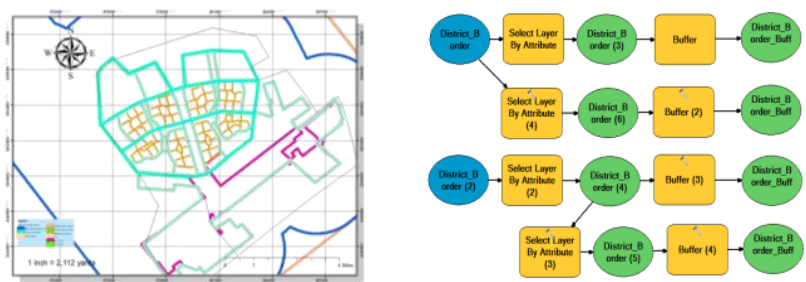

Figure 6. Sanitation

Smart mobility strategy GIS pilot model and map:

These models and maps will be presented in Fig.7,8,9 and 10 bellow for each criteria.
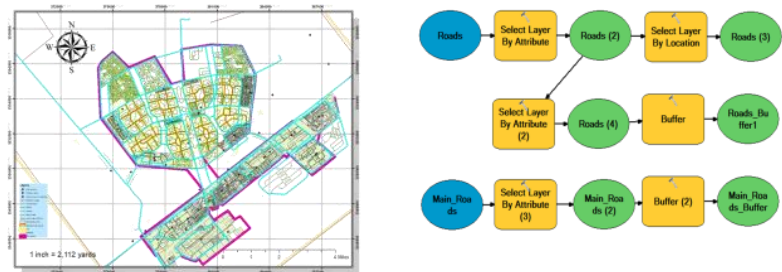

Figure 7. Public / private Transportation condition
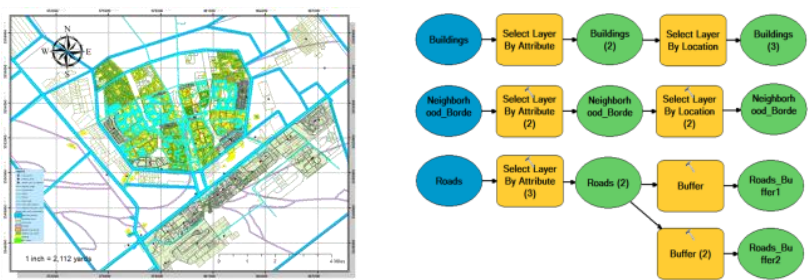

Figure 8. Mobility around the city other than transportation (walkability),
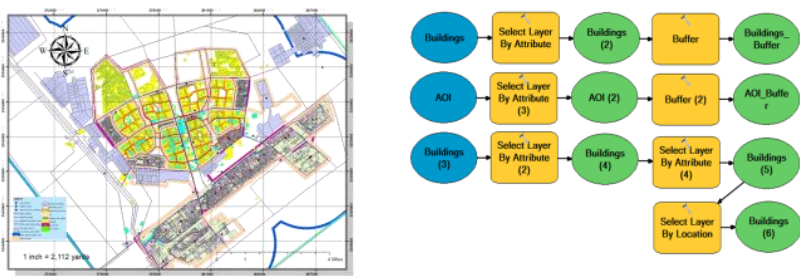

Figure 9. Parking
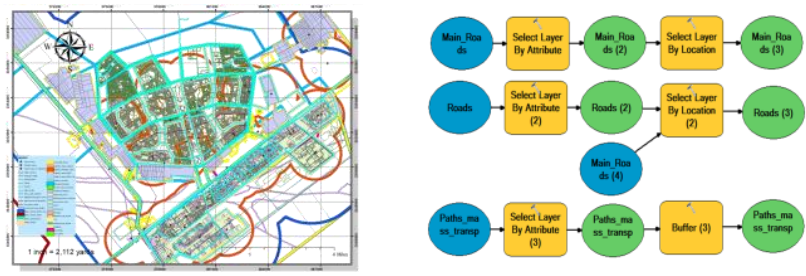

Figure 10. Traffic control 


\section{Smart governance strategy GIS pilot model and map}

These models and maps will be presented in Fig.11 bellow for criteria.
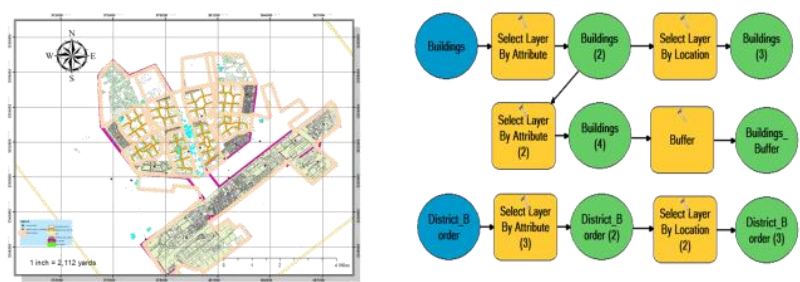

Figure 11. Governance and citizen participation

\section{DISCUSSION AND RESULTS}

Comparative analysis; Analysis the city in response to covid-19 Checklist of the precaution of measures for facing corona virus

1.Wear face mask to avoid the infection of disease

2. Increasing social distance between individuals

3. Wash hands continuously for not less than 20 seconds

4. Away from crowded areas and no congestion

5. Avoid contact with surfaces

6.In the event of touching surfaces, hands are immediately sterilized

\section{Avoid the use of public toilets}

8.Greeting each other from a distance

9. Reducing the attendance of workers in government facilities and the private sectors using online systems.

10.Imdeiate health checking in case of feeling any symptoms

from the speed with which the pandemic was controlled, the collection of data and utilisation of technology during COVID19 , the quarantine period, and the state of the city's economy; Reaching at the end to a smart city that can face any pandemic. Smart cities decrease spread of covid-19 and help in applying the precautionary measures that have been announced by the government and ministry of health. Shown in table 2 below Through reducing the attendance of workers in government facilities and the private sectors using online systems. Decreasing the gatherings and direct individuals interactions, this reduces or limits the risk of spread of covid-19 pandemic.

Table 2.Checklist of precautionary measures(researcher, 2021)

It has been concluded from the above table that by becoming smart city. As shown in table 2 the city will automatically fulfil the precautionary measures that needed to control the spreading of any virus, presented in figure 12 .

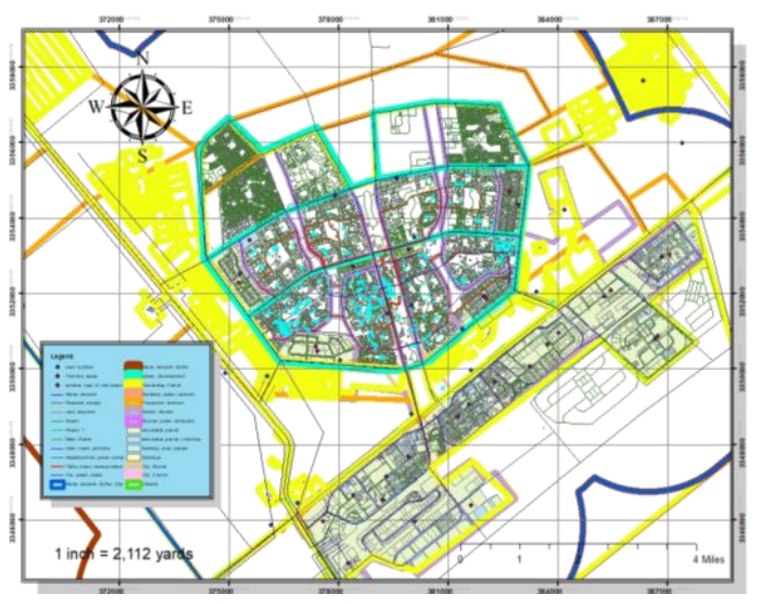

Figure 12. GIS map of all implementation of 10th of Ramadan

\begin{tabular}{|c|c|c|}
\hline $\begin{array}{l}\text { Criteria of } \\
\text { comparison } \\
\text { according to covid- } \\
19\end{array}$ & $\begin{array}{l}10^{\text {th }} \text { of Ramadan } \\
\text { city (Before) }\end{array}$ & $\begin{array}{l}10^{\text {th }} \text { of Ramadan } \\
\text { city (After) }\end{array}$ \\
\hline Quarantine period & $\begin{array}{l}7 \text { month in } \\
1^{\text {st }} \text { wave } \\
4 \text { month } \\
\text { in } 2^{\text {nd }} \text { wave } \\
2 \text { month in } \\
3^{\text {rd }} \text { wave }\end{array}$ & $\begin{array}{l}\text { decrease or even } \\
\text { no lockdown }\end{array}$ \\
\hline $\begin{array}{l}\text { Speed of control of } \\
\text { virus }\end{array}$ & $\begin{array}{l}\text { very slow ,it } \\
\text { took years }\end{array}$ & $\begin{array}{l}\text { control any virus } \\
\text { in its early ages }\end{array}$ \\
\hline $\begin{array}{l}\text { Data collecting and } \\
\text { use of technology }\end{array}$ & low & high \\
\hline $\begin{array}{lr}\text { Spreading } & \text { of } \\
\text { Awareness of near } \\
\text { cases }\end{array}$ & very low & $\begin{array}{ll}\text { very } & \text { high, } \\
\text { immediate } & \\
\text { awareness } & \end{array}$ \\
\hline Economy of city & $\begin{array}{l}\text { Slower } \\
\text { production speed }\end{array}$ & $\begin{array}{l}\text { Normal } \\
\text { production }\end{array}$ \\
\hline
\end{tabular}

Table 3. Comparison before and after the 10th of Ramadan city (researcher, 2021)

\section{CONCLUSION AND RECOMMENDATIONS}

By enhancing the quality of criteria in each strategy this increase the ability to control the spread of any pandemic now and in the future, as presented in table 3.Broadband Internet, sensor networks, and the Internet of Things (IoT) are key additives of any clever metropolis deployment. However, making towns clever calls for extra than simply implementation technology. The following is a listing of guidelines for developing a clever metropolis:

Start with a sensible vision. Smart towns have many one-of-akind drivers and definitions, and no implementations are the same. Clearly imply your city planning, social, economic, outline your finances and plan your project.

Connect, talk and celebrate. 
Deploy your (network) infrastructure "proper the primary time" to create a scalable, manageable, and securely designed IoT infrastructure. Remember, you're building the groundwork for all government-to-government, government-to-citizen, government-to-business, citizen-to-citizen, system-to-person, and system-to-system communication applications. Incorporate clever desires into publicly funded infrastructure plans

\section{REFERENCES}

Abou, T. and Seoud, E. (2014) 'Towards Sustainability: Smart Cities In The Egyptian Environment How much Smart to be Smart?', Journal of Urban Research, 31, p. 2019.

Allam, Z. and Dhunny, Z. A. (2019) 'On big data, artificial intelligence and smart cities', Cities, 89(December 2018), pp. 80-91. doi: 10.1016/j.cities.2019.01.032.

Batty, M. (2018) 'Artificial intelligence and smart cities', Environment and Planning B: Urban Analytics and City Science, 45(1), pp. 3-6. doi: 10.1177/2399808317751169.

Bifulco, Tregua, Amitrano, D. (2016) 'ICT and sustainability in smart cities management | Paper | Microsoft Academic'. Available at: https://academic.microsoft.com/paper/2301068687/reference/se arch?q=ICT and sustainability in smart cities management\&qe=Or(Id\%253D2168452204\%252CId\%253D19 $74963036 \% 252 \mathrm{CId} \% 253 \mathrm{D} 1866654974 \% 252 \mathrm{CId} \% 253 \mathrm{D} 205327$ 9442\%252CId\%253D167368901\%252CId\%253D630736504\% 252CId.

Bowman, J., Mogensan, L., Marsland, E., Lannin, N. (2015) 'The development, content validity and inter-rater reliability of the SMART-Goal Evaluation Method: A standardised method for evaluating clinical goals', Australian Occupational Therapy Journal, 62(6), pp. 420-427. doi: 10.1111/1440-1630.12218.

Clarke, K. C. (1986) 'Advances in Geographic Information Systems', Computers, Environment and Urban Systems, 10(34), pp. 175-184. doi: 10.1016/0198-9715(86)90006-2.

Elsayed, M. A. and Ismaeel, W. S. E. (2019) 'Environmental assessment for major development projects: A case study “ Qattara Depression ", 215, pp. 522-533.

GOPP (2021) General Organization for Physical Planning. Available at: www.gopp.gov.eg.

Govt. of India (2017) 'the Smart City Challenge Smart City Proposal : Rourkela', (7).

Ben Letaifa, S. (2015) 'How to strategize smart cities: Revealing the SMART model', Journal of Business Research. doi: 10.1016/j.jbusres.2015.01.024.

Lorente, L. M. L., Arrabal, A. A. and Pulido-Montes, C. (2020) 'The right to education and ict during covid-19: An international perspective', Sustainability (Switzerland), 12(21), pp. 1-17. doi: 10.3390/su12219091.

Maliene, V., Grigonis, V., Palevicius, V., Griffiths, S. (2011) 'Geographic information system: Old principles with new capabilities', Urban Design International, 16(1), pp. 1-6. doi: 10.1057/udi.2010.25.
Samsonov, T. (2018) Review of The Routledge Handbook of Mapping and Cartography, Cartographic Perspectives. doi: 10.14714/cp91.1505.

Wu, J., Ota, K., Dong, M., Li, C. (2016) 'A Hierarchical Security Framework for Defending Against Sophisticated Attacks on Wireless Sensor Networks in Smart Cities', IEEE Access, 4(c), pp. 416-424. doi: 10.1109/ACCESS.2016.2517321. 